\title{
ASSESSMENT OF POPULATION DENSITY AND STRUCTURE OF PRIMATES IN PANDAM WILDLIFE PARK, PLATEAU STATE, NIGERIA
}

\author{
DENSIDAD POBLACIONAL Y ESTRUCTURA DE PRIMATES \\ DIURNOS EN EL PARQUE DE VIDA SILVESTRE EN PANDAM, \\ ESTADO DE PLATEAU, NIGERIA.
}

\begin{abstract}
Gabriel Ortyom Yager*, James Oshita Bukie and Avalumun Emmanuel Kaa, Department of Wildlife and Range Management, University of Agriculture, Makurdi, Benue State, Nigeria.
\end{abstract}

*Correspondent author email \& Phone: gbrlyager@gmail.com; 08150609846

\begin{abstract}
A survey of diurnal primate species in Pandam Wildlife Park, Nigeria was conducted to determine its population density and structure. Eight transect lines $(2.0 \mathrm{~km}$ length, $0.02 \mathrm{~km}$ width) at interval of $1.0 \mathrm{~km}$ were located as representative samples in the Park within the Three-range stratum (riparian forest, savannah woodland and, swampy area) based on proportional to size of the strata in providing information on the primates' species present in the Park which include Cercopithecus mona, Erythrocebus patas, Papio anubis and, Chlorocebus tantalus. Direct method of animal sighting was employed. Data was collected and analyzed using descriptive statistics, ANOVA and diversity indices. The results showed that savannah woodland strata had more number of individual species encountered (132) and the lowest was the swampy area. Also the savannah woodland had the highest species diversity and richness while the riparian forest strata had the highest number of species evenness. More so, Cercopithecus tantalus was widespread throughout the Park among other primates and Cercopithecus mona is most likely to decline even more rapidly than others since they inhabit the very tall trees. The variation in mean value of primates species sampled were not statistically significance $(P>0.05)$. Generally, one primate can be sighted in every $\mathrm{km}^{2}$ of range strata covered within the park. This census provides update information on the status of primate diversity and numbers within the Park which can help to
\end{abstract}


direct conservation efforts of the primates and other animals by the state government. This will further enhance the sustainability and elevation of the Park to a National Park.

Keywords: Habitat, transect, sighting, diversity, distribution.

\section{RESUMEN}

Se realizó una encuesta de especies de primates diurnas en el parque natural de Pandam, Nigeria, para determinar su densidad de población y estructura. Se localizaron ocho líneas de transecto $(2,0 \mathrm{~km}$ de longitud, 0,02 km de ancho) a intervalos de 1,0 km como muestras representativas en el parque dentro de los tres estratos de rango (bosque ribereño, bosque de sabana y área pantanosa) en función del tamaño al proporcionar información sobre las especies de primates presentes en el parque. Estos incluyen (Cercopithecus mona, Erythrocebus pata, Papio anubis y Chlorocebus tantalus). Método directo de avistamiento de animales fue empleado. Los datos fueron recolectados y analizados usando estadísticas descriptivas, ANOVA e índices de diversidad. El resultado mostró que los estratos boscosos de sabana tenían más especies individuales encontradas (132) y el más bajo era el área pantanosa. También el bosque de sabana tenía la mayor diversidad y riqueza de especies, mientras que el estrato de bosque ribereño tenía el mayor número de especies iguales. Más aún, C. tantalus se extendió por todo el parque, entre otros primates, y $C$. mona es más probable que disminuya incluso más rápidamente que otros, ya que habitan en los árboles muy altos. Sin embargo, la variación en el valor promedio de las especies muestreadas no fue estadísticamente significativa ( $P>0.05)$. Generalmente, al menos un primate puede ser avistado en cada $\mathrm{km}^{2}$ de estratos de rango cubiertos dentro del parque. Este censo proporciona información actualizada sobre el estado de la diversidad y los números de los primates dentro del parque, lo que puede ayudar a dirigir los esfuerzos de conservación de los primates y otros animales por parte del gobierno estatal. Esto mejorará aún más la sostenibilidad y la elevación del parque a un parque nacional.

Palabras clave: estado de la población, primates diurnos, ecología, Parque de Vida Silvestre Pandam. 


\section{INTRODUCTION}

Primates are an important taxonomic group among tropical arboreal fauna and also one of the most dominant in terms of overall biomass (Tashiro, 2001). These include animals such as chimpanzees, gorillas, and monkeys, lemurs, lorises, galagos, pottos, sifakas, indris, aye-ayes and tarsiers (Tyowua et al. 2017). Relatively all primates have common adaptation to living on the trees (arboreal) and all, share the ability to climb by grasping (Ejidike and Okosodo, 2007; Ojo 2016). Primates are also socially interesting animals which exhibits high sense of intelligence, which makes them one of the closest animals to man and command an enormous tourist attraction conserved areas, thus, play a vital role in education and medical research (Ayodele et al. 1999). The species possess a complicated network of interactions among other animals and plant species in the tropical forest ecosystems (Bernard et al., 2016) and serve as good indicator of general health of an ecosystem (Lacher, 2003).

The conservation and protection of wild animal species is enshrined in the Nigerian endangered species of various Decrees. These laws provide for the conservation and protection of wild animal species in Nigeria, unfortunately, most Protected Areas in Nigeria do not have record of animal population abundance and distribution. In some protected areas where such inventories have been carried out, the indirect method of animal assessment (animal dropping, tracts and trails, footprint and calls) are often used in making rough estimates of animal abundance and distribution (Ogogo 2008; Durojaye et al. 2010). However, global primate conservation is a keynote concern especially in Africa (Cowlishaw and Dunbar, 2000) as evidence of population decline is high particularly in Nigeria (Cowlishaw and Dunbar 2000; Oates et al. 2008).

Surveys are method commonly used to document the status of species such as primates and often serve as a good step to long-term studies of population in a given rangeland. An understanding of the structure and composition of primates in different habitat type is important for developing conservation strategies not only for primates but other species with which they interact. Animal distribution is primarily determined by the nature and richness of available habitat, the underlying ecological factors and the relationship to the key components of population ecology. Primates' population dynamics and food components usually influence the density of primates that an area can support (Hohmann et al. 2010). The research therefore seeks to determine the population density and distribution of primates in study area. 


\section{MATERIALS AND METHODS}

Study Area: The Pandam Wildlife Park is located North of Benue River and South of Plateau State, along Lafia-Shendam Road in Quanpan Local Government Area of Plateau State (Ijeomah, 2007). It lies between latitudes $8^{\circ} 35^{\prime} \mathrm{N}$ and $8^{\circ} 55^{\prime} \mathrm{N}$, and longitudes $8^{\circ} 00^{\prime}$ $\mathrm{E}$ and $10^{\circ} 00^{\prime} \mathrm{E}$ (Akosim et al. 2007). It is bounded on the East by Namu and Kayarda towns, on the West and North, by the Dep River and on the South by Aningo, Pandam and Nasukuuk towns (Akosim et al. 2008). It covers a total area of 22,400 km² (Ezealor, 2002). The entire Park lies within the Northern Guinea Savanna (Fig.1). The Pandam Wildlife Park consists of a $\mathrm{Y}$ - shaped lake, which has a length of about three kilometers and the width is between 67-100 m. Major vegetation types of the Park include wooded Guinea Savannah comprising Afzelia africana, Vitellaria paradoxum and Parkia biglobosa. A riparian vegetation mostly observed along the many smaller rivers that form tributaries to the lake and all along the banks of the Pandam lake with the presence of Elais guinensis, Berlina grandiflora and Bosqueia angolense. Marshlands form an open continuous wetland separating the lake and the Savannah vegetation. The two major features of the climate of the Park are divided into wet and dry seasons and the variability from year to year due to climate change. The wet season extend from April to October, while the dry season extends from November to March and annual rainfall in the Park is between 1,000 - 1,500 mm per annum (Ezealor, 2002).

Data Sampling and Collection: The population estimates and status of the Pandam primates were assessed using line transect method as outlined by Stuart and Stuart, (1998) and Peres, (1999). Eight transects (2 from swampy habitat, 3 from woodland habitat and riparian forest each were established). The distribution of transects was based on probability proportional to size. Transect length of $2.0 \mathrm{~km}$ and widths of $0.02 \mathrm{~km}$ were systematically laid, $1.0 \mathrm{~km}$ from each other Bukie et al. 2015 method. Distance along transects was marked with flagging tapes at interval of $0.5 \mathrm{~km}$ for easy identification of animals' location on transects (Fig. 2). Each transect was walked and census was done simultaneously in all the eight established transects. This was done to reduce incidence of double counting as reported by Bukie et al. (2015). During the census the following were noted;

1. Transect number

2. Approximate Right-angle distance to the path of observation walked by the observer

3. Approximate distance of observer to animal sighted

4. Number of primates sighted (Sex, Juvenile, Young and, Adult).

From the information above, the population density of primates was determined according to Ogar, (2009) method as shown in the formula below 
$\mathrm{D}=\frac{\mathrm{N}}{2 \mathrm{LW}}$

Where;

$\mathrm{D}=$ Animal population density (Number $/ \mathrm{km}^{2}$ )

$\mathrm{N}=$ Number of animal sighted

$\mathrm{L}=$ Distance walked by observer $(\mathrm{km})$

$\mathrm{W}=$ Effective stripe width (ESW) $\mathrm{km}$

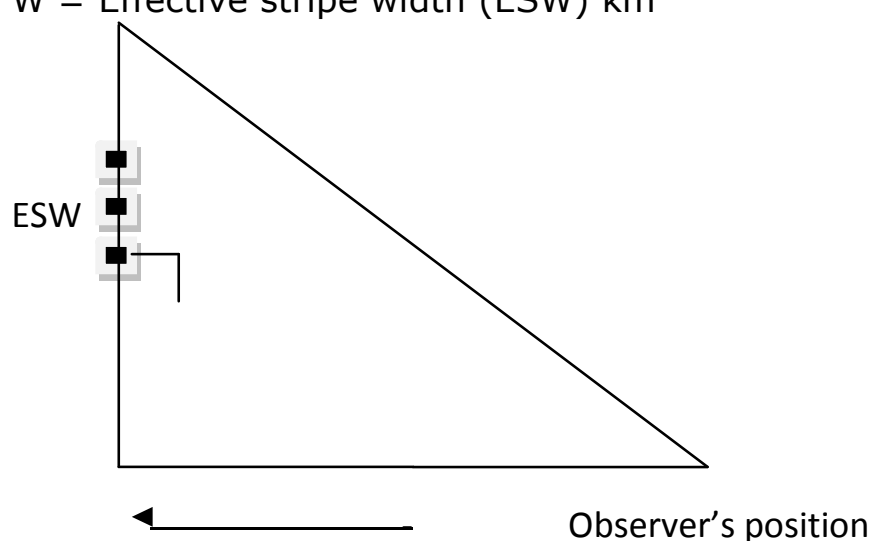

Fig. 2. Diagram of Line transect.

Data Analysis: Descriptive statistics (bar charts, tables) One-Way Analysis of Variance (ANOVA) was used to analyse the difference in means between species sighted (sex and age).

The diversity of species was computed using the Shannon-Wiener diversity index $(H)$ as following (Kent and Coker, 1992):

$$
H=-\sum_{i=1}^{s} p_{i} \ln p_{i}
$$

Where $s$ is the total number of species, $p_{i}$ is the proportion of individuals in the ith species, and $I n$ is the natural logarithm.

Pielou Evenness Index $(E)$ which is a measure of the distribution among species was computed adopting (Pielou, 1969) :

$$
E=\frac{H}{\ln S}
$$

Where $H$ is the Shannon-Wiener function and $S$ is the total number of species

Margalef index (MI) which is a measure of the number of different species represented in the forest community (species richness) was computed as follows;

$$
M I=\frac{S-1}{\ln N}
$$

Where $S$ is the total number of species and $N$ is the number of individuals. 


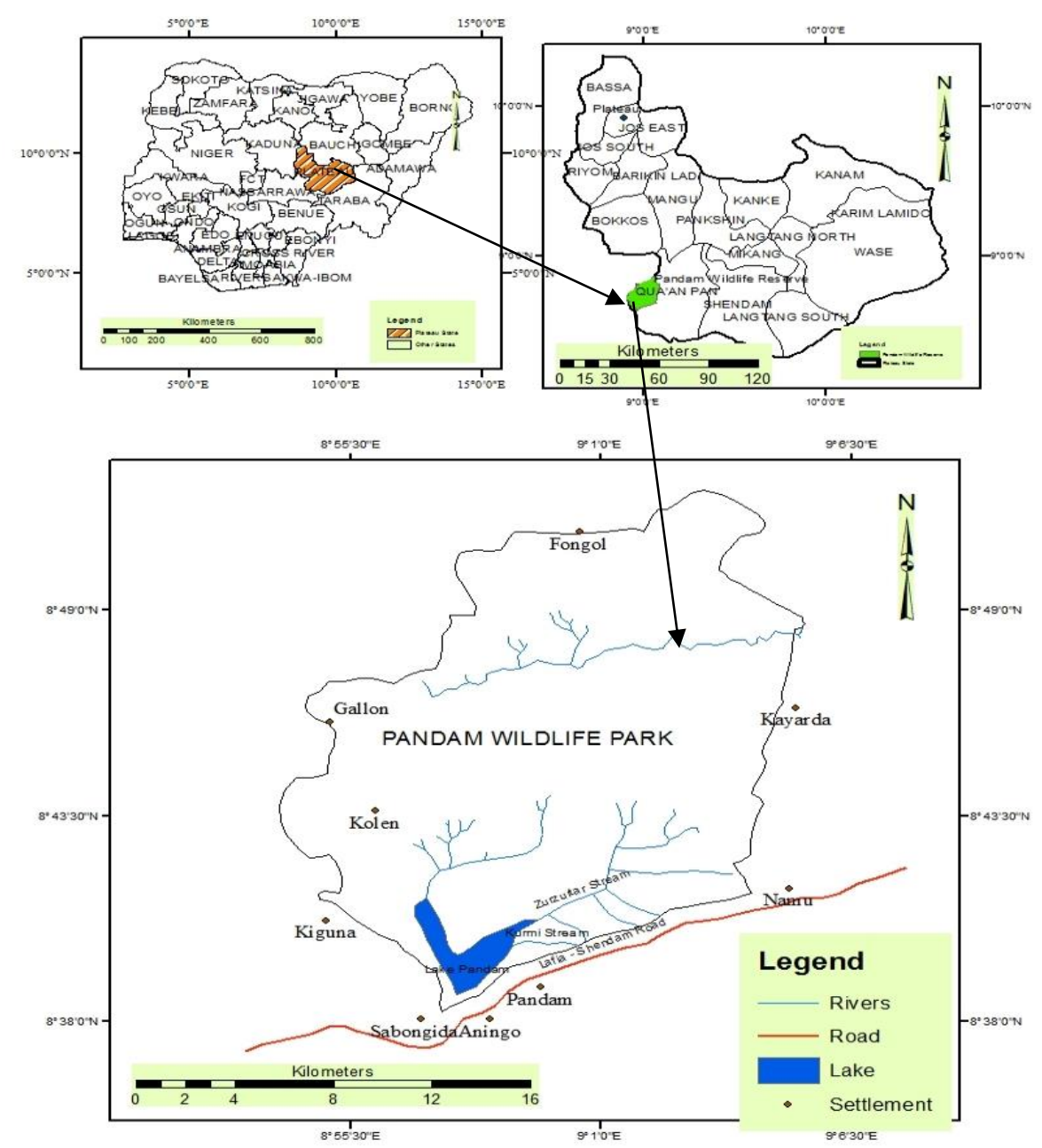

Fig. 1. Map of Nigeria and Plateau State Showing the Study Area

\section{RESULTS}

Primate Species Encountered in the Study Area: Primate species encountered in Pandam Wildlife Park presented in Table 1, revealed that four species belonging to only a family (Cercopithecideae) was observed. All the primate species were three monkeys (Cercopithecus mona, Erythrocebus patas, and, Chlorocebus tantalus) and baboon (Papio anubis). 

Sustainability, Agri, Food and Environmental Research, (ISSN: 0719-3726), 6(2), 2018: 18-35 24
http://dx.doi.org/10.7770/safer-V6N2-art1503

Table 1: Primate Species Sighted in Pandam Wildlife Park.

\begin{tabular}{lll}
\hline Common name & \multicolumn{1}{c}{ Species } & \multicolumn{1}{c}{ Family } \\
\hline Mona monkey & Cercopithecus mona & Cercopithecidae \\
Patas monkey & Erythrocebus patas & Cercopithecidae \\
Olive baboon & Papio anubis & Cercopithecidae \\
Tantalus monkey & Chlorocebus tantalus & Cercopithecidae \\
\hline
\end{tabular}

Source: Field Survey, 2017

Population Density of Primate Species at Different Range Strata (Habitat): Population density of primate species encountered at different range strata shown in Table $2 \mathrm{a}-2 \mathrm{c}$ revealed that, at riparian forest habitat, Tantalus monkey ( $C$. tantalus) had the highest mean species number $(0.72 \pm 0.03)$ while Olive baboon (Papio anubis) has the least $(0.12 \pm 0.02)$. In savannah woodland strata, Mona monkey (C. mona) had the highest mean species number $(0.41 \pm 0.05)$ and the least was Patas monkey (Erythrocebus patas with $0.21 \pm 0.03$. The swampy habitat indicates Mona monkey ( $C$. mona) as the highest occurring species (0.24 \pm 0.01$)$ while the least was Tantalus monkey (C. tantalus) and olive baboon ( $C$. anubis) with corresponding least mean value of $0.08 \pm 0.01$.

Table 2a: Population Density of Primates in Riparian Forest Strata

\begin{tabular}{|c|c|c|c|c|c|c|}
\hline $\begin{array}{l}\text { Transect } \\
\text { Number }\end{array}$ & Species & $\begin{array}{l}\text { Number of } \\
\text { primates } \\
\text { sighted N }\end{array}$ & $\begin{array}{l}\text { Dist. Walked } \\
\text { by observer L } \\
(\mathrm{km})\end{array}$ & $\begin{array}{c}\text { Strip } \\
\text { width W } \\
(\mathrm{Km})\end{array}$ & Transect Density & $\begin{array}{c}\text { Species } \\
\text { Density D }\end{array}$ \\
\hline $\mathrm{T} 1$ & Mona monkey & 0 & 2 & 0 & 0 & \\
\hline $\mathrm{T} 2$ & & 4 & 0.6 & 22 & 0.15 & \\
\hline T3 & & 6 & 0.3 & 30 & 0.33 & $0.16 \pm 0.03$ \\
\hline $\mathrm{T} 1$ & Oliver baboon & 0 & 2 & 0 & 0.00 & \\
\hline $\mathrm{T} 2$ & & 8 & 0.8 & 23 & 0.22 & \\
\hline T3 & & 7 & 1.2 & 19 & 0.15 & $0.12 \pm 0.02$ \\
\hline $\mathrm{T} 1$ & Patas monkey & 2 & 0.2 & 25 & 0.20 & \\
\hline $\mathrm{T} 2$ & & 4 & 1 & 20 & 0.10 & \\
\hline T3 & & 6 & 0.2 & 25 & 0.60 & $0.30 \pm 0.06$ \\
\hline $\mathrm{T} 1$ & Tantalus monkey & 10 & 0.2 & 15 & 1.67 & \\
\hline $\mathrm{T} 2$ & & 6 & 0.5 & 18 & 0.33 & \\
\hline T3 & & 9 & 1.5 & 18 & 0.17 & $0.72 \pm 0.03$ \\
\hline
\end{tabular}



Sustainability, Agri, Food and Environmental Research, (ISSN: 0719-3726), 6(2), 2018: 18-35 25
http://dx.doi.org/10.7770/safer-V6N2-art1503

Table2b: Population Density of Primates in Savannah Woodland Strata

\begin{tabular}{|c|c|c|c|c|c|c|}
\hline Transect & Species & $\begin{array}{l}\text { Number of } \\
\text { primates } \\
\text { sighted N }\end{array}$ & $\begin{array}{l}\text { Dist. Walked } \\
\text { by observer L } \\
(\mathrm{km})\end{array}$ & $\begin{array}{c}\text { Strip } \\
\text { width W } \\
(\mathrm{Km})\end{array}$ & $\begin{array}{l}\text { Transect } \\
\text { Density }\end{array}$ & Species Density D \\
\hline $\mathrm{T} 1$ & Mona monkey & 5 & 0.15 & 25 & 0.67 & \\
\hline $\mathrm{T} 2$ & & 6 & 0.5 & 20 & 0.30 & \\
\hline T3 & & 8 & 0.72 & 22 & 0.25 & $0.41 \pm 0.05$ \\
\hline $\mathrm{T} 1$ & Oliver baboon & 2 & 1.2 & 16 & 0.05 & \\
\hline $\mathrm{T} 2$ & & 10 & 1.5 & 12 & 0.28 & \\
\hline T3 & & 10 & 0.63 & 19 & 0.42 & $0.25 \pm 0.08$ \\
\hline $\mathrm{T} 1$ & Patas monkey & 6 & 0.4 & 20 & 0.38 & \\
\hline $\mathrm{T} 2$ & & 3 & 0.8 & 18 & 0.10 & \\
\hline T3 & & 4 & 0.68 & 18 & 0.16 & $0.21 \pm 0.03$ \\
\hline $\mathrm{T} 1$ & Tantalus monkey & 5 & 0.25 & 18 & 0.56 & \\
\hline T2 & & 10 & 0.65 & 19 & 0.40 & \\
\hline T3 & & 4 & 1.1 & 15 & 0.12 & $0.36 \pm 0.01$ \\
\hline
\end{tabular}

Table 2c: Population Density of primates at Swampy Area

\begin{tabular}{|c|c|c|c|c|c|c|}
\hline Transect & Species & $\begin{array}{l}\text { Number of } \\
\text { primates } \\
\text { sighted N }\end{array}$ & $\begin{array}{l}\text { Dist. Walked by } \\
\text { observer L (km) }\end{array}$ & $\begin{array}{l}\text { Strip width W } \\
\qquad(\mathrm{Km})\end{array}$ & $\begin{array}{l}\text { Transect } \\
\text { Density }\end{array}$ & $\begin{array}{l}\text { Species } \\
\text { Density D }\end{array}$ \\
\hline T1 & Mona monkey & 3 & 0.2 & 22 & 0.34 & \\
\hline T2 & & 5 & 0.77 & 25 & 0.13 & $0.24 \pm 0.01$ \\
\hline $\mathrm{T} 1$ & Oliver baboon & 2 & 0.52 & 20 & 0.10 & \\
\hline T2 & & 4 & 1.9 & 15 & 0.07 & $0.08 \pm 0.01$ \\
\hline T1 & Patas monkey & 5 & 0.45 & 18 & 0.31 & \\
\hline T2 & & 0 & 2 & 0 & 0.00 & $0.15 \pm 0.02$ \\
\hline $\mathrm{T} 1$ & Tantalus monkey & 0 & 2 & 0 & 0.00 & \\
\hline T2 & & 7 & 1.52 & 15 & 0.15 & $0.08 \pm 0.01$ \\
\hline
\end{tabular}

The Mean Variation of Primate Species Sighted (Number, Sex, Age) in the Study Area: The result of the mean variation for primate species observed presented in (Tables $3 a$ - 3c, Figures 3-6) showed that, at the riparian forest strata, Tantalus monkey (C. tantalus) 
Sustainability, Agri, Food and Environmental Research, (ISSN: 0719-3726), 6(2), 2018: 18-35 26 http://dx.doi.org/10.7770/safer-V6N2-art1503

had the highest mean number of species sighted $(6.25 \pm 2.25)$, the least was Mona monkey (C. mona) with 3.33 \pm 1.76 . The sex number for male revealed that, Tantalus monkey ( $C$.

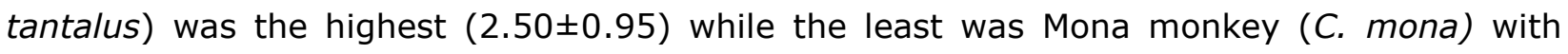
1.33 \pm 0.66 . Female number indicates Tantalus monkey (C. tantalus) as the highest $(2.25 \pm 0.85)$, the lowest Patas monkey (. patas) $(1.33 \pm 0.42)$. The age bracket indicates high value for Tantalus monkey (C. tantalus) $(0.05 \pm 0.50)$ while the last was Mona monkey (C. mona) $(0.00 \pm 0.00)$ for juvenile. The young species had high value in Olive baboon ( $P$. anubis) (1.33 \pm 0.66$)$, the lowest was Patas monkey ( $E$. patas) with $0.16 \pm 0.16$. Furthermore, adult species indicates high value for Tantalus monkey (C. tantalus) (4.75 \pm 1.60 ), the lowest

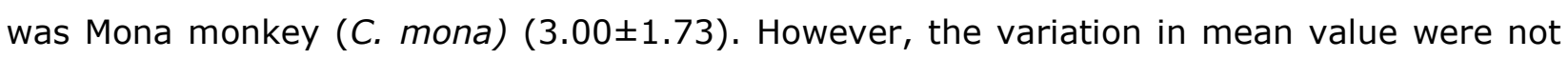
statistically significance $(P>0.05)$.

In the savannah woodland, Tantalus monkey ( $C$. tantalus) had the highest mean

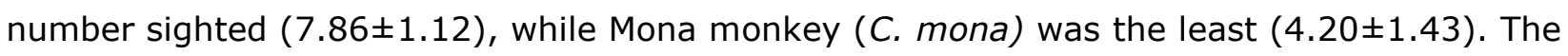
sex number for both male and female indicates that tantalus monkey ( $C$. tantalus) is the highest while the lowest was the Mona monkey ( $C$. mona). The age bracket, Tantalus monkey (C. tantalus) had the highest while the lowest was Mona monkey (C. mona) for juvenile species, Olive baboon ( $P$. anubis) the highest while, the least was Patas monkey ( $E$. patas) for young. Adults had tantalus monkey (C. tantalus) as the highest while the lowest was Mona monkey (C. mona). However, variation in mean for species number sighted and sex were not statistically significant $(P>0.05)$ while for age were statistically significant $(P<0.05)$.

Table 3a: The Mean Variation of Primate Species Sighted (Number, Sex, Age) at Riparian forest

\begin{tabular}{lllllc}
\hline Measurements & \multicolumn{3}{c}{ Primate Species } & \multirow{2}{*}{ P-Value } \\
\cline { 2 - 4 } & Mona Monkey & Oliver Baboon & Patas Monkey & Tantalus Monkey \\
\hline $\begin{array}{l}\text { Number } \\
\text { Sex }\end{array}$ & $3.33 \pm 1.76$ & $5.00 \pm 2.52$ & $4.00 \pm 0.73$ & $6.25 \pm 2.25$ & $0.65^{\mathrm{ns}}$ \\
$\quad$ & & & \\
Male & $1.33 \pm 0.66$ & $2.00 \pm 1.00$ & $2.33 \pm 0.49$ & $2.50 \pm 0.95$ & $0.75^{\mathrm{ns}}$ \\
$\quad$ Female & $1.67 \pm 1.20$ & $1.33 \pm 0.66$ & $1.33 \pm 0.42$ & $2.25 \pm 0.85$ & $0.77^{\mathrm{ns}}$ \\
Age & & & & $0.72^{\mathrm{ns}}$ \\
$\quad$ Juvenile & $0.00 \pm 0.00$ & $0.33 \pm 0.33$ & $0.16 \pm 0.16$ & $0.50 \pm 0.50$ & $0.20^{\mathrm{ns}}$ \\
$\quad \begin{array}{l}\text { Young } \\
\text { Adult }\end{array}$ & $0.33 \pm 0.33$ & $1.33 \pm 0.66$ & $0.16 \pm 0.16$ & $1.00 \pm 0.57$ & $0.80^{\mathrm{ns}}$ \\
\hline
\end{tabular}


Table 3b: The Mean Variation of Primate Species Sighted (Number, Sex, Age) at Savannah woodland.

\begin{tabular}{|c|c|c|c|c|c|}
\hline \multirow[t]{2}{*}{ Measurements } & \multicolumn{3}{|c|}{ Primate Species } & \multicolumn{2}{|c|}{ P-Value } \\
\hline & Mona Monkey & Oliver Baboon & Patas Monkey & Tantalus Monkey & \\
\hline Number & $4.20 \pm 1.43$ & $6.80 \pm 2.42$ & $4.40 \pm 0.81$ & $7.86 \pm 1.12$ & $0.23^{\mathrm{ns}}$ \\
\hline \multicolumn{6}{|l|}{ Sex } \\
\hline Male & $1.60 \pm 0.51$ & $2.40 \pm 0.74$ & $2.40 \pm 0.51$ & $2.57 \pm 0.36$ & $0.32^{\mathrm{ns}}$ \\
\hline Female & $1.60 \pm 0.74$ & $2.40 \pm 1.12$ & $2.20 \pm 0.37$ & $3.42 \pm 0.86$ & $0.46^{\mathrm{ns}}$ \\
\hline \multicolumn{6}{|l|}{ Age } \\
\hline Juvenile & $0.00 \pm 0.00^{b}$ & $0.20 \pm 0.20^{\mathrm{b}}$ & $0.40 \pm 0.24^{\mathrm{ab}}$ & $1.28 \pm 0.42^{\mathrm{a}}$ & $0.02 *$ \\
\hline Young & $1.00 \pm 0.68^{\mathrm{ab}}$ & $1.80 \pm 0.80^{\mathrm{a}}$ & $0.40 \pm 0.24^{b}$ & $0.57 \pm 0.29^{b}$ & $0.02 *$ \\
\hline Adult & $3.20 \pm 1.07^{b}$ & $4.80 \pm 1.59^{\mathrm{ab}}$ & $3.60 \pm 0.40^{\mathrm{b}}$ & $6.28 \pm 0.56^{\mathrm{a}}$ & $0.03 *$ \\
\hline
\end{tabular}

Means on the same row with different superscript are statistically significant

$(p<0.05) ; n s=$ not significant

Table 3c: The Mean Variation of Primate Species Sighted (Number, Sex, Age) at Swampy area

\begin{tabular}{lccccc}
\hline Measurements & \multicolumn{3}{c}{ Primate Species } & P-Value \\
\cline { 2 - 4 } & Mona Monkey & Oliver Baboon & Patas Monkey & Tantalus \\
Monkey & \\
\hline $\begin{array}{l}\text { Number } \\
\text { Sex }\end{array}$ & $3.00 \pm 1.15$ & $3.00 \pm 1.00$ & $2.50 \pm 0.50$ & $3.50 \pm 0.50$ & $0.99^{\mathrm{ns}}$ \\
$\quad$ & & & & \\
$\quad$ Male & $1.33 \pm 0.33$ & $2.00 \pm 0.00$ & $1.00 \pm 0.00$ & $1.50 \pm 0.50$ & $0.86^{\mathrm{ns}}$ \\
$\quad$ Female & $1.33 \pm 0.88$ & $0.50 \pm 0.50$ & $1.00 \pm 1.00$ & $1.00 \pm 1.00$ & $0.92^{\mathrm{ns}}$ \\
Age & & & & \\
$\quad$ Juvenile & $0.00 \pm 0.00$ & $0.00 \pm 0.00$ & $0.00 \pm 0.00$ & $0.50 \pm 0.50$ & $0.37^{\mathrm{ns}}$ \\
$\quad \begin{array}{l}\text { Young } \\
\text { Adult }\end{array}$ & $0.33 \pm 0.33$ & $0.50 \pm 0.50$ & $0.50 \pm 0.50$ & $0.50 \pm 0.50$ & $0.98^{\mathrm{ns}}$ \\
& $2.33 \pm 0.20$ & $2.50 \pm 0.50$ & $2.00 \pm 0.50$ & $2.50 \pm 0.50$ & $0.99^{\mathrm{ns}}$
\end{tabular}

Means are not statistically significant $(p>0.05) ; n s=$ Not significant

In the swampy area, $C$. tantalus had the highest mean number of species sighted while the least was $E$. patas. The sex number for male showed that $P$. anubis was the highest $(2.00 \pm 0.00)$ while the least was $E$. patas $(1.00 \pm 0.00)$. Female indicates $C$. mona as 
the highest species $(1.33 \pm 0.88)$, and Papio anubis was the least $(0.50 \pm 0.50)$. The age bracket indicates that, for juvenile $C$. tantalus was the highest while $C$. mona, $P$. anubis, $E$. patas was the least. For the young stage $P$. anubis, E. patas and $C$. tantalus was the highest while $C$. mona the least. The adult species had $P$. anubis and $C$. tantalus as the highest while E. patas was the least. However, variation in mean numbers were not statistically significant $(P>0.05)$ in this strata. More so, the result of age distribution was represented in the Figures 1-4 across the strata.

Sex Ration among Primate Species in the Study Area: Table 4 showed the ratio of male to female primate species in the study area. The result revealed that $E$. patas and $P$. anubis had the highest number of male than female in riparian forest while in savannah woodland E. patas and C. tantalus had higher females than males. However, P. anubis had the higher number of male than female in swampy area.

Diversity Indices of Primate Species in the Study Area: The result of diversity indices of primate species of this work shown in table 5 revealed that, a total number of 74 individual species were encountered in riparian strata; total of 132 individual species in savanna woodland and a total of 27 were found in the swampy area. The species diversity and richness was higher in the savannah woodland $(H=2.88, D=3.89)$ while, the lowest was recorded in swampy area $(H=1.81, D=1.82)$. However, riparian forest has the highest number of evenness $\mathrm{J}=0.91$.

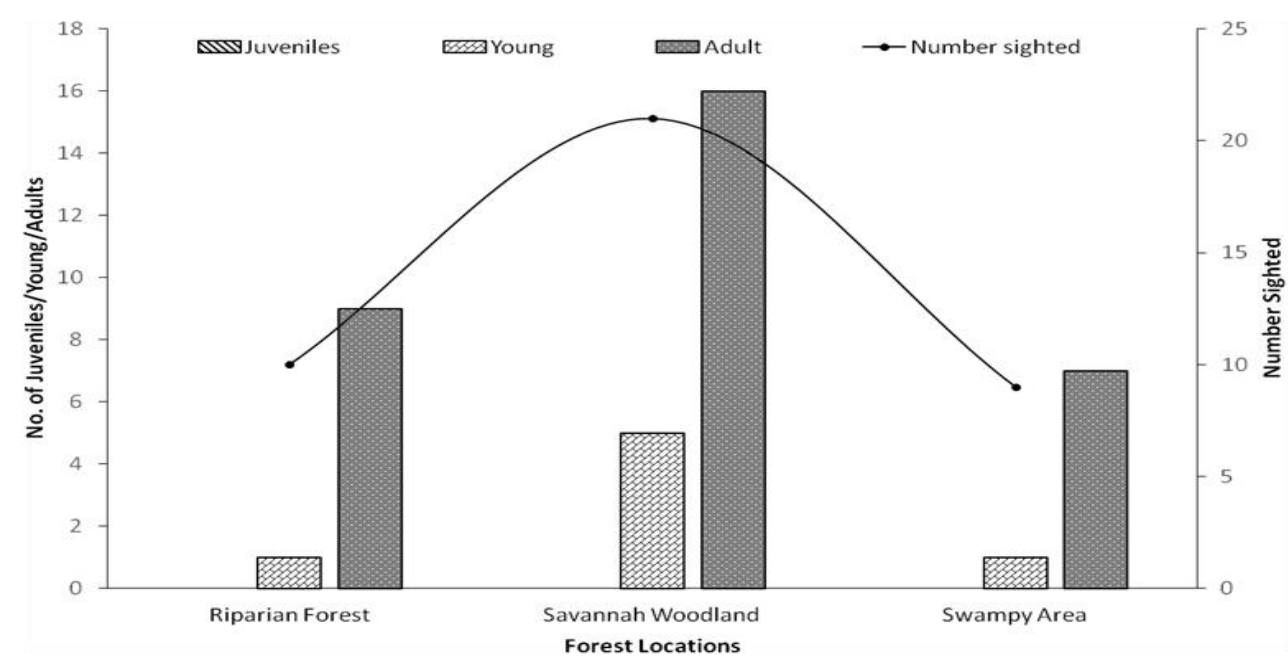

Fig. 3. The Age Distribution of Cercopithecus mona and Number Sighted in the Study Area 
Sustainability, Agri, Food and Environmental Research, (ISSN: 0719-3726), 6(2), 2018: 18-35 29 http://dx.doi.org/10.7770/safer-V6N2-art1503

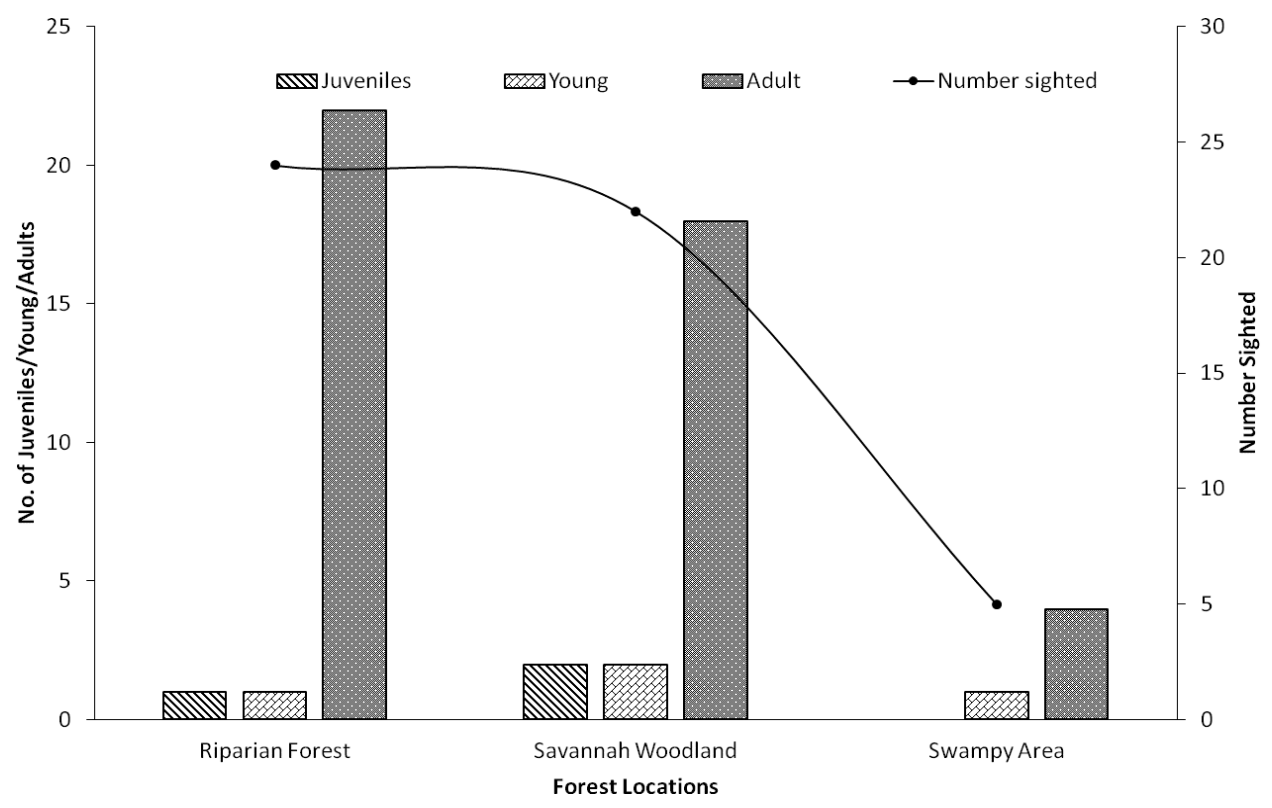

Fig. 4. The Age Distribution of Erythrocebus patas and Number Sighted in the Study Area.

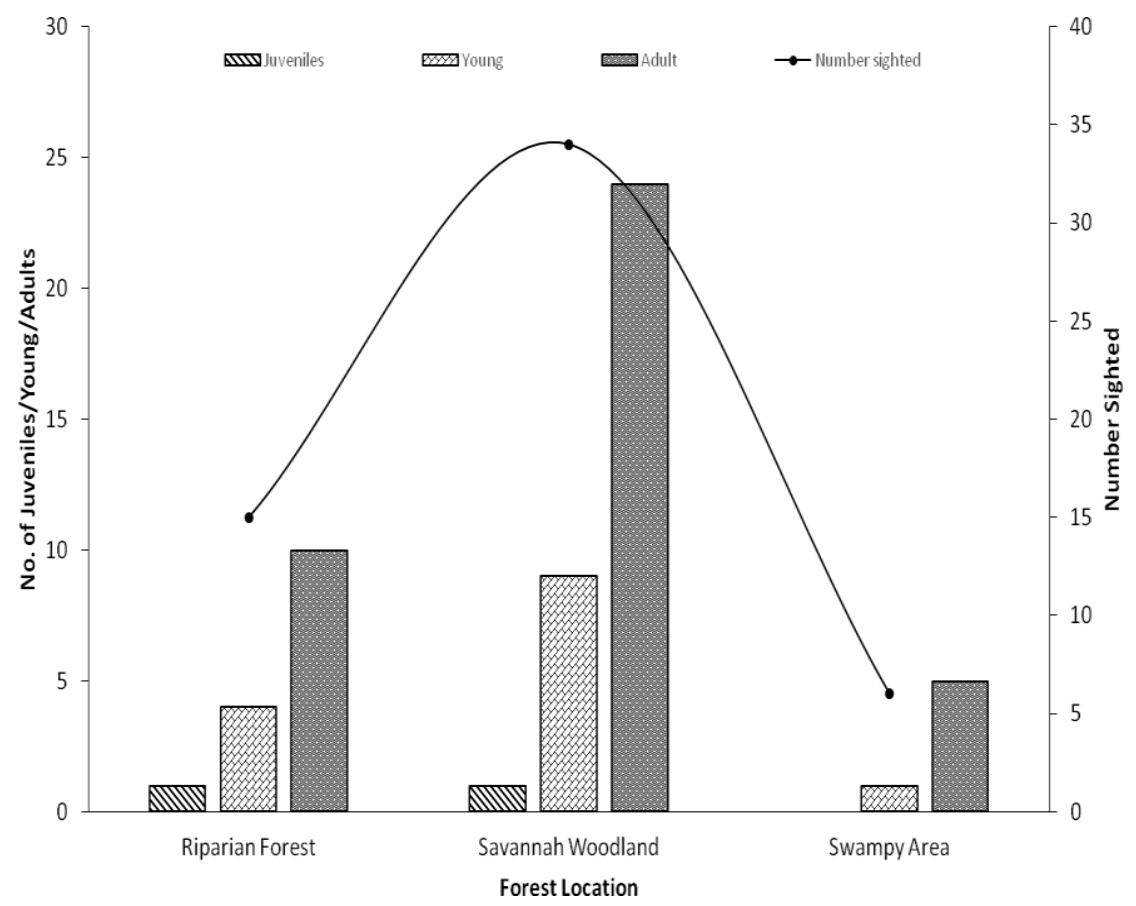

Fig. 5. Age Distribution of Papio anubis and Number Sighted in the Study Area. 
Sustainability, Agri, Food and Environmental Research, (ISSN: 0719-3726), 6(2), 2018: 18-35 30 http://dx.doi.org/10.7770/safer-V6N2-art1503

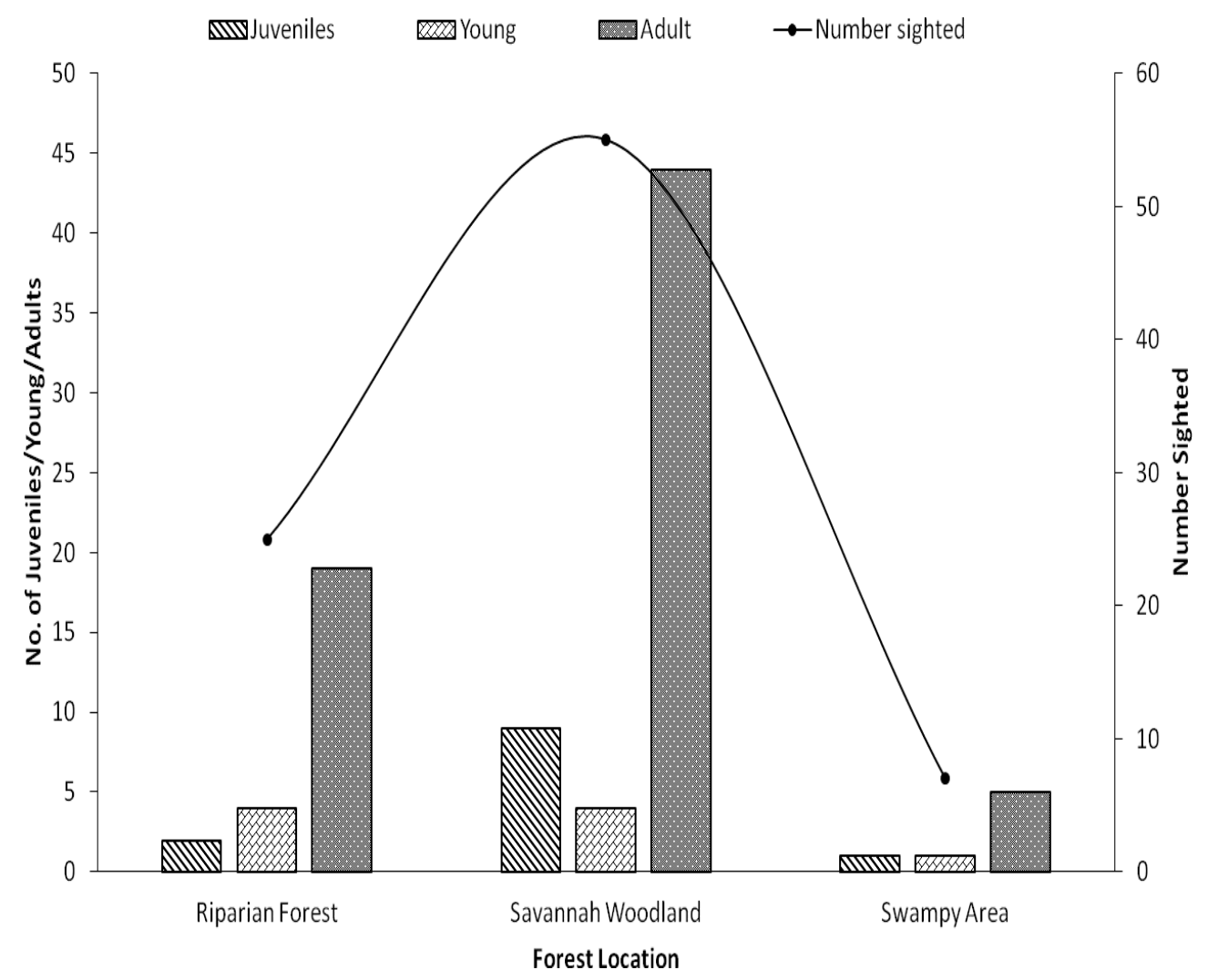

Fig. 6. Age Distribution of Chlorocebus tantalus and Number Sighted in the Study Area.

Table 4: Sex Ration of Primate Species in the Study Area

\begin{tabular}{lccc}
\hline \multicolumn{1}{c}{ Primate Species } & \multicolumn{2}{c}{ Location } \\
\cline { 2 - 4 } & Riparian Forest & Savannah Woodland & Swampy Area \\
\hline Mona Monkey & $1: 1.25$ & $1: 1$ & $1: 1$ \\
Patas Monkey & $1.75: 1$ & $1: 1.57$ & $1: 1$ \\
Tantalus Monkey & $1.11: 1$ & $1: 1.33$ & $1.5: 1$ \\
Oliver Baboon & $1.5: 1$ & $1: 1$ & $4: 1$ \\
\hline
\end{tabular}

Source: Field Survey, 2017 
Table 5: Diversity Indices of Primate Species in Study Area

\begin{tabular}{lccc}
\hline Diversity Indices & \multicolumn{2}{c}{ Location } \\
\cline { 2 - 4 } & Riparian Forest & Savannah Woodland & Swampy Area \\
\hline Individuals & 74 & 132 & 27 \\
Dominance D & 0.09 & 0.06 & 0.17 \\
Simpson 1-D & 0.90 & 0.93 & 0.82 \\
Shannon H & 2.47 & 2.88 & 1.81 \\
Evenness e^H/S & 0.91 & 0.89 & 0.87 \\
Margalef & 2.78 & 3.89 & 1.82 \\
Berger-Parker & 0.13 & 0.09 & 0.25 \\
\hline
\end{tabular}

\section{DISCUSSION}

The relatively high diversity of primate species found in the study area is typical of West African taxa and may not be unconnected to the fact that the species are not accepted as meat by the people in the surrounding communities. Similar observation was made by Mbaya and Malguui, (2010) at Sambisa game reserve. Although, only four primates species were encountered (C. mona, Er. pata, P. anubis and C. tantalus) against eight and five species as reported by Ojo, (2016) in Old Oyo National park and Tyowua et al. (2017) in Gashaka-Gumti National park. However, there was a variation in the list of species encountered. This probably could be as a result of difference in the location of the study sites. Primates have diversified habitat, usually arboreal except baboon which possess many characteristics that aid its adaptation to environment. This was observed among species distribution across different range strata in the study area. Some primate species invaded the woodland and savannah habitat of Africa from their ancestral forest homes but not totally since they tend to be restricted to the riparian and swampy areas.

The field observation and analysis of results showed that savannah woodland strata had more number of individual species enumerated (132). Specifically, C. tantalus was widespread throughout the park (range stratum) with the highest species density in the savannah woodland strata. This could be as a result of the fact that, the vegetation structure at the savannah woodland is relatively undisturbed and can support the species in terms of habitat requirement compared to the riparian forest strata and the swampy area. Similar report was made by Modu et al. (2010) at Sambisa game reserve. Survey and findings has it 
that, there were good numbers of $P$. erinaceous within the riparian and swampy area. The tree species alongside others were heavily logged for foreign exchange and furniture making thus, result to habitat destruction in that part of the park. This probably is one of the reasons why specie's composition in the stratum was low. In the same vein, Hohman et al., (2010) and Bukie et al. (2015) report that, area that can support primate is greatly influenced by habitat stability in terms of food availability, cover and safety. Meanwhile, $E$. patas was higher in the riparian forest. This suggests $E$. patas as a ground dwelling mediumsized primate fitting into the vegetation that was almost open. The vegetation has satisfied one of Patas behavioral traits as been running on the ground as reported by De Jong et al. (2009). However, there was no significant difference among species distribution within the range stratum except for age bracket observed in the savannah woodland.

The ratio of male to female was analyzed based on the habitat difference and the observation made indicated that, the male to female of $E$. pata and $P$. anubis in the study area was unstable. C. tantalus and C. mona indicated a stable ration, population and the most adaptive species in the savannah woodland and riparian forest strata. The result of diversity indices of primate obtained also confirmed that, species diversity and richness was higher in the savannah woodland $(H=2.88, D=3.89)$ while, the lowest was recorded in swampy area $(H=1.81, D=1.82)$. However, riparian forest had the highest number of species evenness $(\mathrm{J}=0.91)$ indicating that it was well represented in terms of species distribution. Generally, at least one primate can be sighted in every $\mathrm{km}^{2}$ of range strata covered within the park. In Nigeria many wild animals' species are becoming extinct as a result of changes in their natural habitats. Primates at Pandam Wildlife Park are also in this category, facing significant threats in their natural ranges as a result of habitat degradation through deforestation and farming activities. This clearly illustrates the compelling need to protect the park in order to restore the balance of population structure. Until there is a reapproach towards the management and protection of the park, the future of these primates and other wildlife species are threatened.

The rate of extinction of species when their habitat is destroyed is dependent on the size of the habitat patch left undisturbed and the group of organisms concerned. Among the four species of monkeys encountered in the Park, C. mona is most likely to decline even more rapidly than others since they inhabit the very tall trees.

We suggest that, regular population assessment of primates in the Park should be conducted to ascertain the population trend for effective management policies and conservation. 


\section{ACKNOWLEDGMENTS}

We are grateful to the management of Pandam Wildlife Park for the permission and support given to us especially the Park manager and the staff.

\section{REFERENCES}

Akosim, C., Kwaga, B. T., Ali, A. \& Mamman, G .S. 2007. Flora resources and structure in Pandam Wildlife Park, Plateau State, Nigeria. Agric. J. 2:740-747.

Akosim, C., Kwaga, B.T., Umar, B. \& Mamman, G. S. 2008. The role of aquatic bodies in avifauna and fish conservation in Pandam Wildlife Park, Pandam, Plateau State Nigerian J. Fish. Int. 3:7-11.

Ayodele, I.A.,Ebin, C. O. \& Alarape, A.A. 1999. Essentials of Wildlife Management.Published by Jacchin Publisher, Ibadan. Pp $10-45$.

Bernard, H., Bili, R., Matsuda, I., Hanya, G., Oliver, R., Wong, A. \& Almad, A.H. 2016. Species Richness and Distribution of Primates in Disturbed and Converted Forest Landscape in Northern Borneo. Tropical Cons. Sci.. 2016: 1-11

Bukie, J. O., Ebu, V. T. \& Nchor, A. A. 2015. Population Ecology of the White-Throated Monkey (Cercopithecus erythrogaster) in Afi Mountain Wildlife Sanctuary (AMWS), Cross River State, Nigeria. Int. J.f Agricult. Forest., 5: 245-248.

Cowlishaw. G. \& Dunbar, R. 2000. Primate conservation Biology Chicago. University of Chicago press. Pp 3-24.

De Jong, Y. A., Butynski, T. M., Isbell, L. A. \& Lewis, C. 2009. Decline in the geographical range of the southern Patas monkey (Erythrocebus patas baumstarki) in Tanzania. Oryx 43: 267-274

Durojaye, G., Ejidike, B. N. \& Bello, M. A. 2010. Relative abundance and distribution of roan antelope Hippotragus equinus in Borgu sector of Kainji lake National, New Bussa, Nigeria. Proceedings of the second Biennial National conference of the Forest and Forestt products society, field at the Fedral University of Technology, Akure, Nigeria onyekwelu, J.C., Adekunle, v.a, AND Oke, D.O. (Eds) p.501-504.

Ejidike, B. N. \& Okosodo, F. E 2007. Food and feeding habits of the thick-tailed Galago (Otelemur crassicaudatus) in Okomu National Park P. J F I 2: 231-233. 

Sustainability, Agri, Food and Environmental Research, (ISSN: 0719-3726), 6(2), 2018: 18-35
http://dx.doi.org/10.7770/safer-V6N2-art1503

Ezealor, H. U. 2002. Critical sites for conservation in Nigeria. Nigerian Conservation Foundation, Lagos, Nigeria. 46-47.

Hohmann, G., Potts, K. N'guessan, A. 2010. Plant foods consumed by Pan: Exploring the variation of nutritional ecology across Africa. American J. Phys. Anthropol. 141: 476485.

Ijeomah, H. M. 2007. Impact of tourism on perceived poverty alleviation in Plateau State. Ph.D Thesis Department of Wildlife and Fisheries Management, University of Ibadan. 2007; 301

Kent, M. and Coker, P. 1992. Vegetation Description and Analysis: A Practical Approach, Chichester. UK: John Wiley \& Sons.

Lacher, T. E. 2003. Tropical Ecology, Assessment and monitoring (TEAM) initiative. Primate monitoring protocol. Conservation international. Washintong D.C. pp 2-10.

Mbaya, Y. P. and Malgwi, H. (2010). Species list and status of mammals and birds in Sambisa game reserve, Borno State, Nigeria. J. Res. For. Wildlife Env.. 2: 135-140.

Modu, M. Alarape, A. A. Omifolaji, J. K. \& Burabe B. I. 2015. Relative Density an Distribution of Tantalus Monkey (Cercopithecus Tantalus) in the Four Ranges of Sambisa Game Reserve, J. Res. For. Wildlife Env. 7: 54- 58.

Oates, J. F. 2008. Primate Behavioral Ecology. pp. 182-185.

Ogar, D. A. 2009. Fundamentals of Forestry and Wildlife Management in Nigeria. Unical Printing Press, University of Calabar, Calabar. 122p.

Ogogo, A. U. 2008. Wildlife management in Nigeria, Objectives, principles and procedures printed by Unical printing press, published by median communication 39, Hart Street, Calabar, Cross River State, Nigeria. 278pp.

Ojo, F. T. 2016. Assessment of the population dynamics of diurnal primates in Old Oyo National park, Nigeria. Int. J. Sci. Res. Educ., 9: 48-90.

Peres, C. A. 1999. General Guidelines for standardizing line-transect surveys of Tropical Forest Primates. Neotrop. Prim. 7: 11-16.

Pielou, E. C. An Introduction to Mathematical Ecology. 1969. New York, NY, USA: Wiley. $286 \mathrm{p}$.

Stuart, C. \& Stuart, T. 1998. African's vanishing Wildlife. Smithsonian Institutional Press U.S.A, PP 240-250. 1998. 
Sustainability, Agri, Food and Environmental Research, (ISSN: 0719-3726), 6(2), 2018: 18-35 35 http://dx.doi.org/10.7770/safer-V6N2-art1503

Tashiro, Y. 2001. Ecological factors influencing primate abundance and feeding activity in the Kalinzu Forest, Uganda, Kyoto, Japan: Kyoto University. Pp 3 -10.

Tyowua, B. T, Yager G. O. \& Samuel D. E. 2017 Feeding Ecology of Primates in Southern Sector of Gashaka-Gumti National Park (Filinga Range), Taraba State, Nigeria. AJEE 2(3): 1-9.

Received: 24 $4^{\text {th }}$ April 2018.

Accepted: $28^{\text {th }}$ May 2018. 